PENGARUH STRATEGI BAURAN PEMASARAN TERHADAP KINERJA PEMASARAN DENGAN ORIENTASI KEWIRAUSAHAAN SEBAGAI VARIABEL PEMODERASI PADA UPPKS (USAHA PENINGKATAN PENDAPATAN KELUARGA SEJAHTERA) DI KOTA PEKANBARU PEKANBARU

\title{
PENGARUH STRATEGI BAURAN PEMASARAN TERHADAP KINERJA PEMASARAN DENGAN ORIENTASI KEWIRAUSAHAAN SEBAGAI VARIABEL PEMODERASI PADA UPPKS (USAHA PENINGKATAN PENDAPATAN KELUARGA SEJAHTERA) DI KOTA PEKANBARU
}

\author{
Rizal Rahmat ${ }^{1}$, Zulkarnain ${ }^{2}$, Alvi Furwanti Alwie ${ }^{3}$ \\ ${ }^{1)}$ Mahasiswa Program Pascasarjana Universitas Riau \\ 2),3) Dosen Program Pascasarjana Universitas Riau \\ Email : rizalrahmat555@gmail.com ${ }^{1}$
}

\begin{abstract}
One of the concerns of the government in efforts to reduce poverty is through the BKKBN (National Population and Family Planning Agency), namely by organizing the UPPKS (Prosperous Family Income Improvement Program) program as a family economic empowerment program through the learning of economic businesses by inspiring family interest and enthusiasm for entrepreneurship. UPPKS groups in Pekanbaru City have produced many products that are actually quite attractive and even needed by the community. However, not all UPPKS products are known by the wider community. UPPKS products are mostly made if there are only orders, even though the UPPKS group has the potential to produce products that have a sale value and are mass produced to be sold widely. In the absence of certainty in the amount of production due to the weak marketing strategy, the income received by members of the UPPKS group is unstable, so there is no continuous certainty. The objectives of this research are: To find out and analyze the influence of marketing mix strategies, entrepreneurial orientation and marketing mix which is moderated by entrepreneurial orientation on marketing performance in UPPKS groups in Pekanbaru City. The object of this research was conducted on 29 business groups incorporated in the UPKKS assisted by Pekanbaru City BKKBN. The population in this study were 29 UPPKS groups in Pekanbaru with a total membership of 315 people. Determination of the number of samples was represented by 3 people from each UPPKS group, so the number of samples was 77 people. The data used are primary data through questionnaires. The research analysis tool is Path Analysis with the Multiple Regression Analysis method. The results showed that the marketing mix, and entrepreneurial orientation had a significant effect on marketing performance. The marketing mix strategy if it is moderated by entrepreneurial orientation has a significant influence on marketing performance. Entrepreneurial orientation is an indispensable variable because it can increase the influence of the marketing mix on marketing performance.
\end{abstract}

Keywords : UPPKS, BKBN, Marketing Mix Strategy, Entrepreneurial Orientation, and Marketing Performance. 


\section{PENDAHULUAN}

Perkembangan penduduk di Indonesia dari tahun ke tahun terus mengalami peningkatan. Hal ini bisa dilihat dari laporan Badan Pusat Statitistik yang menyatakan bahwa jumlah penduduk Indonesia tahun 2012 sebesar 206,2 juta jiwa dan menjadi 237,6 juta jiwa pada tahun 2017. Pertumbuhan jumlah penduduk ini sebesar $13,76 \%$ atau dengan kata lain bertambah sebanyak 32,5 juta jiwa. Jumlah tersebut akan terus meningkat di tahun berikutnya apabila pembangunan kependudukan yang dilakukan pemerintah tidak digalakkan lagi, yaitu melalui program Keluarga Berencana (KB).

Tingginya pertumbuhan jumlah penduduk tersebut menimbulkan suatu permasalahan klasik di Indonesia yaitu masalah kemiskinan. Hal ini terjadi karena tingginya pertumbuhan jumlah penduduk tidak diimbangi dengan tingkat pendidikan yang baik sehingga kualitas SDM menjadi rendah dan terbatasnya jumlah lapangan pekerjaan. Kemiskinan merupakan keadaan dimana tingkat pendapatan seseorang tidak mencukupi untuk memenuhi kebutuhan pokoknya. Masalah kemiskinan sampai saat ini masih terus menjadi permasalahan penting di Indonesia. Penduduk miskin pada umumnya tidak berdaya atau kurang memiliki keterampilan dalam mengembangkan diri menuju pada taraf sejahtera (Suyanto, 2013:3).

Badan Pusat Statistik (BPS) menunjukkan bahwa sampai dengan bulan Desember 2018 jumlah penduduk Indonesia yang miskin dengan pendapatan per kapita per bulannya dibawah garis kemiskinan berjumlah 30,02 juta orang atau sekitar 12,49\%. Untuk wilayah Provinsi Riau jumlah penduduk miskin pada tahun 2018 mengalami penurunan sebesar 3,96\% menjadi 494,26 ribu orang dari 514,64 ribu orang pada tahun 2017. Sementara pertumbuhan jumlah penduduk miskin di wilayah Kota Pekanbaru juga mengalami fluktuasi, rata-rata selama 5 tahun terakhir 2014-2018 masih cukup tinggi yakni sebanyak 32.832 orang atau sebesar 3,65\% dengan perincian seperti dalam Tabel 1.1 sebagai berikut:

Tabel 1.1 Jumlah Penduduk Miskin di Kota Pekanbaru Tahun 2014 -2018

\begin{tabular}{|c|c|c|c|}
\hline Tahun & Jumlah Penduduk & Jumlah Penduduk Miskin & Persentase \\
\hline 2014 & 728.388 & 32.517 & 4,46 \\
\hline 2015 & 811.025 & 32.292 & 3,98 \\
\hline 2016 & 903.038 & 33.763 & 3,74 \\
\hline 2017 & 1.064 .566 & 32.491 & 3,05 \\
\hline 2018 & 1.091 .088 & 33.095 & 3,03 \\
\hline
\end{tabular}


diprogramkan pemerintah sebagai salah satu langkah efektif dalam upaya penanggulangan kemiskinan baik melalui kelembagaan yang bersifat lembaga departemen maupun non departemen. Kebijakan pemerintah tersebut tertuang dan dijelaskan dalam Undang-Undang Nomor 10 Tahun 1992 tentang Perkembangan Kependudukan dan Pembangunan Keluarga Sejahtera yang pelaksanaannya di atur dalam Inpres Nomor 3 Tahun 1996 tentang Pembangunan Keluarga Sejahtera

Dalam Rangka Peningkatan Penanggulangan Kemiskinan.

Untuk mewujudkan hal tersebut pemerintah telah memfasilitasinya dalam bentuk badan umum milik negara. Salah satunya adalah melalui lembaga BKKBN (Badan Kependudukan dan Keluarga Berencana Nasional) yakni dengan menyelenggarakan program UPPKS (Usaha Peningkatan Pendapatan Keluarga Sejahtera) sebagai program pemberdayaan ekonomi keluarga. Program UPPKS ini merupakan program yang pelaksanaannya diintegrasikan dengan program KB (Keluarga Berencana), yang bertujuan untuk meningkatkan kondisi ekonomi keluarga. Tanpa kondisi ekonomi yang baik, mustahil keluarga akan dapat meningkatkan kualitas kehidupannya. Kegiatan usaha ini telah dirintis dan dipelopori oleh BKKBN yang merupakan model usaha mikro keluarga. Berfungsi untuk menggerakkan roda ekonomi keluarga melalui pembelajaran usaha ekonomi dengan cara menggugah minat dan semangat keluarga untuk berwirausaha.

Tujuan dibentuknya kelompok UPPKS ini diantaranya adalah untuk mengembangkan dinamika kelompok, meningkatkan kesertaan KB, meningkatkan pendapatan keluarga, mengembangkan kemandirian keluarga, dan memantapkan fungsifungsi keluarga, yang pada akhirnya kelompok ini dapat mengantarkan anggotanya menjadi wirausaha yang mandiri, dalam rangka meningkatkan kesejahteraan keluarga (Fatma, 2014).

Program UPPKS ini dilaksanakan secara nasional sejak tahun 1992. Ditujukan untuk semua wilayah, tidak hanya di daerah pedesaan, namun juga di perkotaan terutama daerah kumuh dan miskin. Salah satu ciri kondisi kampung perkotaan kumuh yaitu sangat padat dengan permukiman warga, dan menghadapi berbagai persoalan multidimensi, sosial, kesehatan, dan lingkungan. Umumnya semua persoalan tersebut tidak terlepas dari permasalahan pokok yaitu ekonomi. Di Kota Pekanbaru sendiri, sampai dengan Bulan Juli 2019 sudah terdapat 29 kelompok UPPKS dengan jumlah anggota mencapai 315 orang dan tersebar pada 12 Kecamatan. Secara rinci dapat dilihat dalam Tabel 1.2 sebagai berikut: 
PENGARUH STRATEGI BAURAN PEMASARAN TERHADAP KINERJA PEMASARAN DENGAN ORIENTASI KEWIRAUSAHAAN SEBAGAI VARIABEL PEMODERASI PADA UPPKS (USAHA PENINGKATAN PENDAPATAN KELUARGA SEJAHTERA) DI KOTA PEKANBARU PEKANBARU

Tabel 1.2 Jumlah dan Anggota UPPKS di Pekanbaru Sampai Juli 2019

\begin{tabular}{|c|l|c|c|c|}
\hline No & \multicolumn{1}{|c|}{ Nama UPPKS } & Kecamatan & Kelurahan & $\begin{array}{c}\text { Jumlah } \\
\text { Anggota } \\
\text { (Orang) }\end{array}$ \\
\hline 1 & Karya Mandiri & Tampan & Tuah Karya & 8 \\
\hline 2 & Hidup Berkah Berkarya & Tampan & Sialang Munggu & 8 \\
\hline 3 & Buah Madani & Tampan & Tuah Madani & 8 \\
\hline 4 & Maju Bersama & Tampan & Sidomulyo Barat & 8 \\
\hline 5 & Suka Damai Mandiri & Tampan & Sidomulyo Barat & 8 \\
\hline 6 & Tunas Sejahtera & Tampan & Air Puth & 8 \\
\hline 7 & Berkah Bersama & Tampan & Air Putih & 8 \\
\hline 8 & Gemilang Bersama & Marpoyan Damai & Tangkerang Tengah & 6 \\
\hline 9 & Mekar Wangi & Marpoyan Damai & Tangkerang Barat & 8 \\
\hline 10 & Mekar Sari & Payung Sekaki & Labuh Baru Timur & 9 \\
\hline 11 & Restu Ibu & Payung Sekaki & Sungai Sibam & 9 \\
\hline 12 & Siak Berkah & Payung Sekaki & Tampan & 9 \\
\hline 13 & Jari Ibu & Rumbai Pesisi & Limbungn Baru & 7 \\
\hline 14 & Kembang Sepatu & Rumbai Pesisi & Meranti Pandak & 9 \\
\hline 15 & Bunga Ros & Rumbai & Sri Meranti & 10 \\
\hline 16 & Mekar Berseri Indah & Tenayan Raya & Sialang Rampai & 19 \\
\hline 17 & Dwi Kora & Sail & Suka Mulya & 13 \\
\hline 18 & Sekar Wangi & Bukit Raya & Tangkerang Labui & 15 \\
\hline 19 & Sumber Rezeki & Bukit Raya & Tangkerang Labui & 13 \\
\hline 20 & Utama Sejahtera & Bukit Raya & Simpang Tiga & 23 \\
\hline 21 & Mutiara Madani & Bukit Raya & Tangkerang Selatan & 18 \\
\hline 22 & Harapan Madani & Bukit Raya & Tangkerang Utara & 18 \\
\hline 23 & Melati Putih & Sukajadi & Kampung Tengah & 7 \\
\hline 24 & Sejahtera & Pekanbaru Kota & Sukaramai & 11 \\
\hline 25 & Pucuk Rebung & Pekanbaru Kota & Kota Baru & 3 \\
\hline 26 & Tiga Dara & Senapelan & Kampung Bandar & 8 \\
\hline 27 & Serumpun & Lima Puluh & Sekip & 18 \\
\hline 28 & Tiga Dara & Lima Puluh & Rintis & 14 \\
\hline 29 & Usaha Mandiri & Tanjung Rhu & 12 \\
\hline & & Jumlah Anggota & & $\mathbf{3 1 5}$ \\
\hline & Sum : & & \\
\hline
\end{tabular}

Sumber : BKKBN Kota Pekabaru, Juli 2019.

Dari 29 kelompok UPPKS yang ada di Kota Pekanbaru tersebut sudah banyak menghasilkan produkproduk yang sebenarnya cukup diminati bahkan dibutuhkan oleh masyarakat. Mulai dari produk hasil kerajinan tangan seperti pakaian atau baju dengan bordiran, jilbab, songket, bros, taplak meja hingga makanan ringan seperti keripik singkong, keripik jamur, keripik wortel, lempuk durian, aneka kue kering dan kue basah khas Melayu serta berbagai produk cindra mata lainya yang secara kualitas tidak kalah dengan produk hasil pabrikan atau usaha skala besar. Dari segi harga dan kemasannyapun sebenarnya pruduk yang dihasilkan 
PENGARUH STRATEGI BAURAN PEMASARAN TERHADAP KINERJA PEMASARAN DENGAN ORIENTASI KEWIRAUSAHAAN SEBAGAI VARIABEL PEMODERASI PADA UPPKS (USAHA PENINGKATAN PENDAPATAN KELUARGA SEJAHTERA) DI KOTA PEKANBARU PEKANBARU

kelompok UPPKS tersebut dapat bersaing karena harga yang ditawarkan sudah kompetitif serta dengan kemasan yang juga sudah baik dan menarik.

Singh dan Pandya (1991), Dengan tidak adanya kepastian dalam jumlah produksi karena masih lemahnya strategi pemasaran yang selama ini hanya berdasarkan pesanan saja hal ini menyebabkan pendapatan yang diterima oleh anggota kelompok UPPKS menjadi tidak stabil sehingga tidak adanya kepastian yang berkesinambungan. Hasil penjualan kelompok UPPKS hanya besar pada saat adanya pesanan untuk kegitan bazar atau pameran saja, hal ini dapat dilihat dari pola data penjualan seperti terlihat dalam Tabel 1.3 sebagai berikut :

Tabel 1.3 Data Penjualan Bulanan Tiga Tahun Terakhir 29 Kelompok UPPKS di Kota Pekanbaru

\begin{tabular}{|c|c|c|c|}
\hline \multirow[b]{2}{*}{ Bulan } & \multicolumn{3}{|c|}{ Tahun } \\
\hline & $\begin{array}{r}2017 \\
(\mathrm{Rp})\end{array}$ & $\begin{array}{c}\mathbf{2 0 1 8} \\
(\mathrm{Rp})\end{array}$ & $\begin{array}{c}\text { 2019* } \\
\text { (Rp) }\end{array}$ \\
\hline Januari & 17.700 .000 & 13.500 .000 & 10.200 .000 \\
\hline Februari & 27.550 .000 & 34.500 .000 & 10.150 .000 \\
\hline Maret & 36.000 .000 & 40.000 .000 & 35.000 .000 \\
\hline April & 32.200 .000 & 45.400 .000 & 37.700 .000 \\
\hline Mei & 28.000 .000 & 38.000 .000 & 35.000 .000 \\
\hline Juni & 25.000 .000 & 40.000 .000 & 45.000 .000 \\
\hline Juli & 60.000 .000 & 68.000 .000 & 75.000 .000 \\
\hline Agustus & 70.000 .000 & 70.000 .000 & 0 \\
\hline September & 32.800 .000 & 42.500 .000 & 0 \\
\hline Oktober & 20.500 .000 & 30.000 .000 & 0 \\
\hline November & 32.200 .000 & 38.000 .000 & 0 \\
\hline Desember & 32.200 .000 & 23.500 .000 & 0 \\
\hline Jumlah & 414.150 .000 & 483.400 .000 & 248.050 .000 \\
\hline Rata-Rata & 34.512.500 & 40.283.333 & 20.670 .833 \\
\hline
\end{tabular}

Sumber : BKKBN Kota Pekabaru, Juli 2019.

Catatan : Data tahun 2019 sampai bulan Juli.

Dalam Tabel 1.3 jika dicermati, terlihat bahwa pola penjualan yang dilakukan oleh kelompok UPPKS setiap tahunnya hampir sama. Penjualan akan meningkat pada bulan-bulan tertentu saja yakni pada bulan Juli dan Agusutus. Hal ini karena pada bulan- bulan tersebut adanya kegiatankegiatan bazar maupun pameran yang dilakukan oleh instansi-instansi yang ada di lingkungan Pemerintahan Kota Pekanbaru yang melibatkan kelompok UPPKS untuk berpartisipasi dalam rangka mempromosikan hasil produkproduk yang mereka hasilkan. Hal ini membuktikan bahwa kinerja pemasara kelompok UPPKS di Kota Pekanbaru masih lemah dan hanya 
mengandalkan adanya pesananpesanan saja. Kemudian jika dilihat dari rata-rata hasil penjualannyapun masih sagat kecil.

Menyikapi hal tersebut untuk lebih meningkatkan kinerja pemasaran kelompok UPPKS, upaya yang dilakukan saat ini adalah selain melakukan promosi melalui bazar dan pameran, mereka juga sudah mencoba strategi pemasaran lain namun masih bersifat tradisional yakni dengan menitipkan produk-

produk yang dihasilkan pada warung-warung disekitar tempat tinggal mereka. Hal ini dilakukan dalam rangka upaya mereka untuk meningkatkan kinerja pemasaran yang diharapkan akan dapat meningkatkan omzet penjualan. Namun sayangnya strategi tersebut tidak dapat berjalan dengan baik dan bahkan seringkali omzet yang mereka targetkan tidak tercapai. Padahal sebagus apapun produk yang dihasilkan tidak akan diketahui konsumen tanpa adanya pemasaran yang mendukung. Hal ini seringkali membuat para pelaku usaha terutama usaha dengan skala kecil sulit untuk bertahan.
Lemahnya penetrasi pasar dan kurang luasnya jangkauan wilayah pemasaran menjadi permasalahan mendasar yang dihadapi oleh para pelaku usaha kecil termasuk apa yang dialami oleh kelompok UPPKS di Kota Pekanbaru. Penduduk Kota Pekanbaru masih banyak yang belum mengetahui akan produk-produk dari kelompok UPPKS. Berdasarkan hasil wawancara yang dilakukan dengan beberapa pengurus kelompok UPPKS dapat disimpulkan bahwa strategi pemasaran produk UPPKS saat ini masih belum efektif karena tidak semua masyarakat Kota Pekanbaru mengetahui keberadaan UPPKS dan produk-produk apa saja yang telah dihasilkan. Pernyataan ini diperkuat dengan hasil studi pendahuluan yang dilakukan melalui penyebaran kuesioner terhadap 30 orang responden masyarakat Kota Pekanbaru. Responden tersebut diambil secara acak dengan teknik random sapling yang tersebar pada 12 Kecamatan dalam wilayah Kota Pekanbaru. Hasil studi pendahuluan tersebut dapat dilihat pada Gambar 1.1 berikut: 


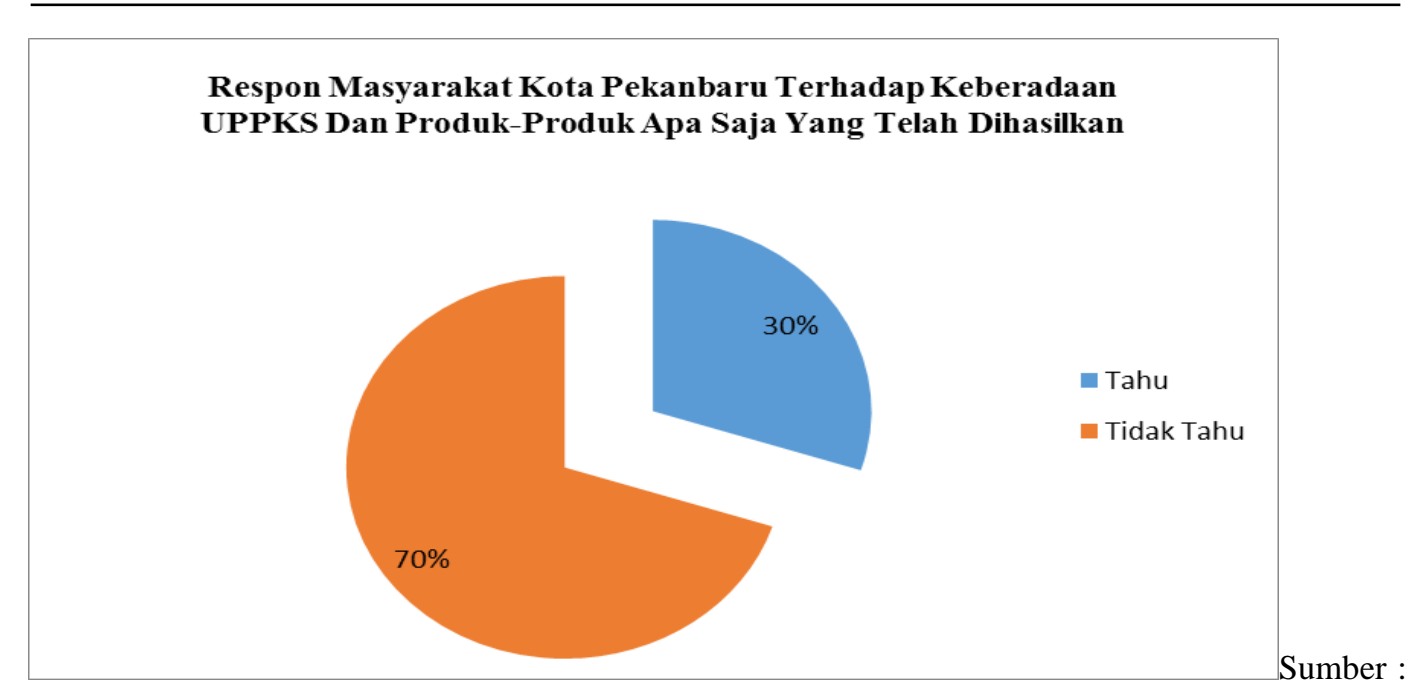

Olahan data studi pendahuluan 2019.

Gambar 1.1 Grafik Respon Masyarakat Kota Pekanbaru Terhadap Keberadaan UPPKS dan Produk-Produk Apa Saja Yang Telah Dihasilkan

Gambar 1.1 menunjukan bahwa dari 30 orang responden masyarakat Kota Pekanbaru tersebut ternyata hanya $30 \%$-nya saja yang mengetahui tentang keberadaan kelompok UPPKS dan produkproduk apa saja yang telah meraka hasilkan, sedangkan 70\% lainya tidak mengetahuinya. Hasil ini semakin memperjelas bahwa kinerja pemasaran dengan satrategi pemasaran yang selama ini dilakukan dalam upaya mengenalkan keberadaan kelompok UPPKS dengan produk-produk yang dihasilkannya masih belum efektif dan kurang promosi.

\section{Strategi}

pemasaran merupakan wujud rencana yang disusun untuk mencapai suatu tujuan yang diinginkan seperti kemajuan perusahaan dalam mengembangkan usaha (Rachmawati, 2011). Dalam mencapai target penjualan pengusaha dapat membuat strategi pemasaran yang dapat meningkatkan target penjulan khususnya bagi kelompok UPPKS. Salah satu strategi yang dapat dilakukan adalah dengan menggunakan bauran pemasaran (marketing mix) yang meliputi Product, Price, Promotion dan Place (Rachmawati, 2011). Kotler dan Armstrong (2014), mendefinisikan marketing mix as the set of controllable marketing variables that the firm bleads to produce the response it wants in the target market. Pengelolaan bauran pemasaran yang tepat akan memberi banyak manfaat bagi perusahaan. Strategi bauran pemasaran dapat menjadi keunggulan tersendiri bagi perusahaan yang tidak dimiliki pesaingnya.

\section{Kinerja}

pemasaran merupakan salah satu syarat dalam pencapaian tujuan usaha. Pencapaian tujuan usaha diperoleh dari upaya pelaku usaha dalam mengelola usaha dengan baik yang didasari oleh bauran pemasaran yang tepat agar kinerja pemasaran dalam suatau usaha tercapai dan bahkan 
meningkat. Pengelolaan usaha yang dilakukan pelaku usaha tercermin dari kinerja yang dihasilkan dan pencapaian tujuan dalam usaha tersebut. Dengan demikian, bauran pemasaran sangat penting bagi pelaku usaha dalam pencapaian tujuan pada usahanya, sebab akan mencerminkan kinerja pemasaran secara keseluruhan. Hal ini sesuai dengan hasil penelitain yang dilakukan oleh Hendri (2016), Risal dan Salju (2017), Karinda, Lisbeth dan Mananeke (2018), serta Yulianeu (2019), yang menyimpulkan bahwa strategi bauran pemasaran yang meliputi product, price promotion dan price berpengaruh signifikan terhadap kinerja pemasaran. Akan tetapi hasil berbeda ditunjukan oleh penelitian Angelita dan Silvya (2018), yang menyimpulkan bahwa dari keempat dimensi bauran pemasaran hanya product, price dan promotion yang berpengaruh terhadap kinerja pemasaran. Sedangkan place tidak berpengaruh terhadap kinerja pemasaran. Kemudian penelitian yang dilakukan oleh Fiandri (2016), tentang analisis strategi bauran pemasaran terhadap kinerja pemasaran pada usaha mikro, kecil, dan menengah (UMKM) Sektor Fesyen. Hasil penelitiannya menyimpulkan bahwa hanya dimensi product yang berpengaruh terhadap kinerja pemasaran sedangkan price, promotion dan place tidak berpengaruh terhadap kinerja pemasaran.

Atas fenomena tersebut dan masih ditemukannya suatu kesenjangan (research gap) atau perbedaan terhadap hasil dari beberapa penelitian-penelitian sebelumnya, membuat peneliti ingin melakukan penelitian ini dengan alasan bahwa peneliti ingin : memahami, mengukur dan mempertimbangkan bagimana strategi bauran pemasaran dapat mempengaruhi kinerja pemasaran dengan orientasi kewirausahaan sebagai variabel pemoderasi pada khususnya kelompok UPPKS (Usaha Peningkatan Pendapatan Keluarga Sejahtera) di Kota Pekanbaru dalam bentuk Tesis dengan judul: "Pengaruh Strategi Bauran Pemasaran Terhadap Kinerja Pemasaran Dengan Orientasi Kewirausahaan Sebagai Variabel Pemoderasi Pada Kelompok UPPKS (Usaha Peningkatan Pendapatan Keluarga Sejahtera) Di Kota Pekanbaru".

\section{KERANGKA TEORI}

\section{Strategi}

Strategi adalah pendekatan secara keseluruhan yang berkaitan dengan pelaksanaan gagasan, perencanaan, dan eksekusi sebuah aktivitas dalam kurun waktu tertentu. Secara khusus strategi adalah "penempatan" misi peerusahaan, penetapan sasaran organisasi dengan mengingat kekuatan eksternal dan internal, perumusan kebijakan dan strategi tertentu untuk mencapai sasaran dan memastikan implementasinya secara tepat, sehingga tujuan dan sasaran utama organisasi akan tercapai Supriono (2009:8).

Menurut Supriono (2009:8), strategi adalah penentuan dasar goal jangka panjang dan tujuan perusahaan serta pemakaian caracara dan alokasi sumber-sumber 
yang diperlukan untuk mencapai tujuan. Sedangkan Fuad (2010:4), mengatakan bahwa strategi dan taktik adalah memenangkan suatu persaingan. Persaingan ini berbentuk suatu pencampuran fisik untuk merebut suatu wilayah dengan memakai senjata tajam dan tenaga manusia sedangkan dalam bidang militer dan taktik adalah suatu cara atau teknik memenangkan suatu persainagn antara kelompokkelompok yang berbeda orientasi hidupnya.

\section{Strategi Pemasaran}

Pemasaran merupakan salah satu dari kegiatan-kegiatan pokok yang dilakukan oleh para pengusaha dalam usahanya untuk mempertahankan kelangsungan hidupnya, untuk berkembang, dan mendapatkan laba. Berhasil tidaknya dalam pencapaian tujuan bisnis tergantung pada keahlian mereka di bidang pemasaran, produksi, keuangan, maupun bidang lain. Selain itu juga tergantung pada kemampuan mereka untuk mengkombinasi fungsi-fungsi tersebut agar organisasi dapat berjalan lancar. Swastha (2010:5), menyatakan bahwa pemasaran adalah suatu sistem keseluruhan dari kegiatan-kegiatan bisnis yang ditujukan untuk merencanakan, menentukan harga, mempromosikan, dan mendistribusikan barang dan jasa yang memuaskan kebutuhan baik kepada pembeli yang ada maupun pembeli potensial.

Strategi pemasaran menurut Kotler dan Amstrong (2014:3), adalah suatu proses sosial dan manajerial yang didalamnya individu dan kelompok mendapatkan apa yang dibutuhkan dan diinginkan dengan menciptakan, menawarkan, dan mempertukarkan produk yang bernilai dengan pihak lain. Pengertian tersebut menunjukkan bahwa strategi pemasaran mengandung aspek sosial baik secara individu maupun berkelompok untuk memenuhi kebutuhan dan keinginannya, akibat adanya keinginan dan kebutuhan tersebut maka terciptalah suatu interaksi yang disebut transaksi pertukaran barang dan jasa. Tujuannya adalah bagaimana memenuhi keinginan dan kebutuhan konsumen baik terhadap individu maupun kelompok. Strategi pemasaran merupakan alat fundamental yang direncanakan untuk mencapai tujuan perusahaan dengan mengembangkan keunggulan bersaing yang berkesinambungan melalui pasar yang dimasuki dan program pemasaran yang digunakan untuk melayani pasar sasaran tersebut (Tjiptono, 2014:315).

\section{Manajemen Pemasaran}

Manajemen pemasaran merupakan hal yang penting dalam suatu perusahaan untuk mengetahui bagaimana memasarkan produk, bagaimana melakukan riset agar produk yang ditawarkan diminati pembeli. Perusahaan yang bergerak dibidang produksi dan jasa pun tidak akan terlepas dari banyak kegiatan, salah satunya pemasaran (marketing). Berikut adalah beberapa definisi manajemen pemasaran menurut teori para ahli:

Kotler dan Armstrong (2014:30), mendefinisikan manajemen pemasaran sebagai berikut, The art and science of choosing target markets and building profitable relationships with them.

Kemudian Kotler dan Keller 
(2016:27), mendefinisikan marketing management as the art and science of choosing target markets and getting, keeping and growing customers through creating, delivering, and communicating superior customer value. Sedangkan pengertian manajemen pemasaran menurut Buchari (2014:130), adalah perencanaan, pengarahan, dan kontrol atas seluruh aktivitas pemasaran suatu perusahaan atau divisi dari suatu perusahaan.

\section{Bauran Pemasaran (Marketing Mix)}

Salah satu tujuan perusahaan yang utama adalah untuk mendapatkan laba yang diperoleh perusahaan dari hasil produksinya dan untuk mempertahankan kelangsungan hidup perusahaan dalam perluasan usahanya. Adapun salah satu yang menjadi ukuran mengenai baik buruknya suatu perusahaan bisa dilihat dari tingkat penjualan produknya, semakin tinggi tingkat penjualannya semakin baik pula kinerja perusahaan, begitu juga sebaliknya. Di dalam ruang lingkup pemasaran terdapat apa yang dinamakan dengan bauran pemasaran (marketing mix). Bauran pemasaran merupakan serangkaian variabel pemasaran yang harus dikuasai dan dipahami oleh perusahaan untuk dapat mencapai tujuan perusahaan.

Bauran

pemasaran

merupakan bagian dari konsep pemasaran yang mempunyai peranan yang cukup penting dalam mempengaruhi konsumen untuk membeli produk atau jasa yang ditawarkan. Buchari (2014:131), yang mengaatakan bahwa bauran pemasaran adalah strategi mencampur kegiatan-kegiatan marketing agar dicari kombinasi maksimal sehingga mendatangkan hasil yang paling memuaskan.

\section{Kinerja Pemasaran}

Kinerja pemasaran merupakan ukuran prestasi yang diperoleh dari aktifitas proses pemasaran secara menyeluruh dari sebuah perusahaan atau organisasi. Selain itu, kinerja pemasaran juga dapat dipandang sebagai sebuah konsep yang digunakan untuk mengukur sampai sejauh mana prestasi pasar yang telah dicapai oleh suatu produk yang dihasilkan perusahaan. Namun demikian, masalah pengukuran kinerja menjadi permasalahan dan perdebatan klasik karena sebagai sebuah konstruk, kinerja pemasaran bersifat multidimensional yang mana di dalamnya termuat beragam tujuan dan tipe organisasi. Oleh karena itu kinerja sebaiknya diukur dengan menggunakan berbagai kriteria pengukuran sekaligus.

Kinerja pemasaran adalah sebuah prestasi (achievement) yang dihasilkan oleh dampak dari berbagai peran yang berfungsi dalam sebuah organisasi (Ferdinand, 2014:14). Sampurno (2010:173), mendefenisikan kinerja pemasaran adalah akumulasi hasil akhir dari seluruh aktivitas dan proses kerja dari prusahaan atau suatu tampilan keadaan secara utuh atas perusahaan selama periode waktu tertentu, yang merupakan hasil atau prestasi yang dipengaruhi oleh kegiatan operasional perusahaan dalam memanfaatkan sumber-sumber daya yang dimiliki. 


\section{Orientasi Kewirausahaan}

Menurut Muchtolifah

(2010:53), orientasi kewirausahaan merupakan kapabilitas organisasi dalam memberikan kontribusi penciptaan sumberdaya organisasi yang unik, keunggulan posisional yang berpengaruh terhadap kinerja. Menurut Risnawati dan Noermijati (2009:18), orientasi kewirausahaan merupakan orientasi strategi perusahaan dalam berwirausaha untuk memperoleh keunggulan kompetitif dengan indikator: pengambilan keputusan, praktek dan metode.

$\begin{array}{cr}\text { Sedangkan } & \text { Sudjana } \\ \text { (2011:35), berpendapat bahwa }\end{array}$ kewirausahaan merupakan sikap dan perilaku wirausaha. Wirausaha ialah orang yang inovatif, antisipatif, inisiatif, pengambil risiko dan berorientasi laba. Menurut Untoro dan Tim Guru Indonesia (2010:21), kewirausahaan adalah suatu keberanian untuk melakukan upayaupaya memenuhi kebutuhan hidup yang dilakukan oleh seseorang, atas dasar kemampuan dengan cara memanfaatkan segala potensi yang dimiliki untuk menghasilkan sesuatu yang bermanfaat bagi dirinya dan orang lain.

Dari beberapa pendapat para ahli diatas mengenai orientasi kewirausahaan, maka dapat disimpulkan bahwa orientasi kewirausahaan adalah kemampuan para pelaku usaha kelompok UPPKS dalam mengelola sumberdaya agar mampu melakukan strategi dalam berwirausaha sehingga memperoleh keunggulan kompetitif.

\section{Program Usaha Peningkatan Pendapatan Keluarga Sejahtera}

\section{(UPPKS}

Kelompok

Usaha

Peningkatan Pendapatan Keluarga Sejahtera (UPPKS)

adalah kelompok yang melakukan kegiatan ekonomi produktif untuk meningkatkan pendapatan keluarga dalam rangka mewujudkan keluarga kecil bahagia dan sejahtera yang beranggotakan, baik ibu/ibu wanita dari keluarga prasejahtera, keluarga sejahtera I, maupun keluarga lain yang tahap kesejahteraannya lebih tinggi, baik yang belum, sedang, maupun purna peserta KB.

\begin{tabular}{lrr}
\multicolumn{3}{c}{ Tujuan umum dari kelompok } \\
UPPKS & adalah & untuk \\
memberdayakan & ibu-ibu/wanita di \\
bidang ekonomi & sebagai upaya \\
peningkatan & penanggulangan \\
kemiskinan dalam & rangka \\
membangun kemandirian r dan \\
ketahanan keluarga r serta \\
mewujudkan keluarga kecil, bahagia, \\
dan sejahtera.
\end{tabular}

Tujuan umum dari kelompok UPPKS adalah untuk memberdayakan ibu-ibu/wanita di bidang ekonomi sebagai upaya peningkatan penanggulangan kemiskinan dalam rangka membangun kemandirian dan ketahanan keluarga serta dan sejahtera. 


\section{Kerangka Penelitian}

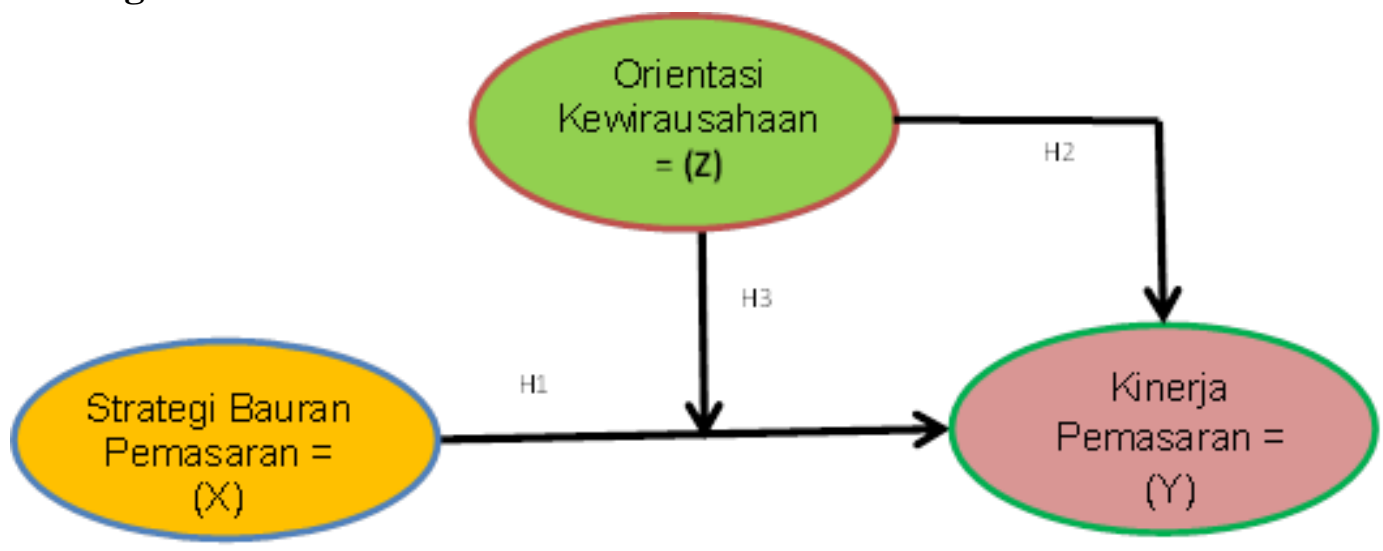

\section{Hipotesis}

Adapun perumusan hipotesis atas pengujian yang dilakukan adalah sebagai berikut:

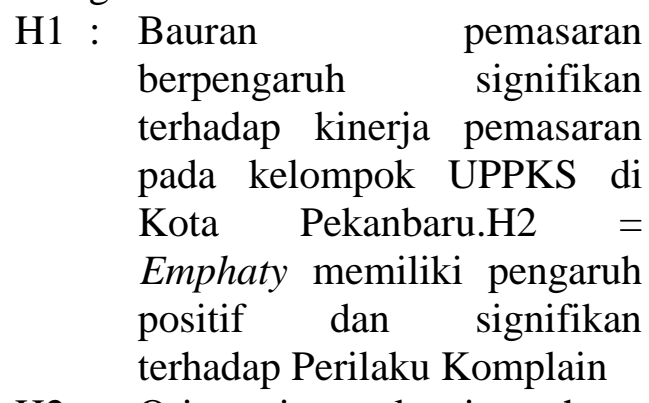

$\mathrm{H} 2$ : Orientasi kewirausahaan berpengaruh signifikan terhadap kinerja pemasaran

pada kelompok UPPKS di Kota Pekanbaru.

H3 : Orientasi kewirausahaan memoderasi dan memperkuat pengaruh bauran pemasaran terhadap kinerja pemasaran.

\section{METODE PENELITIAN}

\section{Lokasi dan Waktu Penelitian}

Penelitian ini dilakukan pada 29 kelompok usaha yang tergabung dalam UPPKS binaan BKKBN Kota Pekanbaru. Sedangakn waktu penelitian ini direncanakan pelaksanaannya selama dua bulan yaitu pada bulan September s/d Oktober 2019.

\section{Jenis dan Sumber Data}

Dalam penelitian ini jenis data yang dibutuhkan adalah data kuantitatif dan didukung dengan data kualitatif, yang menjelaskan keadaan 29 kelompok UPPKS di Kota Pekanbaru yang secara eksplisit, melalui wawancara langsung dengan responden sebagai sampel penelitian. Sumber data diperoleh dari data primer dan data sekunder.

\section{Data Primer}

Data primer diperoleh langsung dari Ketua, Sekretaris dan Bendahara dari setiap Kelompok UPPKS di Kota Pekanbaru tersebut melalui kuesioner.

\section{Data Sekunder}

Data sekunder adalah Data sekunder diperolah melalui informasi dari kantor BKKBN Kota Pekanbaru.

\section{Populasi dan Sampel}

Pada penelitian ini populasinya adalah 29 kelompok UPPKS di Kota Pekanbaru dengan jumlah anggota mencapai 315 orang. 
Sedangkan penentuan jumlah sampel yang akan digunakan dalam penelitian ini diambil dengan menggunakan metode sensus sehingga seluruh kelompok UPPKS di Kota Pekanbaru tersebut diambil sebagai sampel. Responden yang akan diambil sebagai sampel dalam penelitian ini akan diwakili oleh 3 orang dari setiap kelompok UPPKS di Kota Pekanbaru.

\section{Teknik Pengumpulan Data}

Teknik pengumpulan data dalam penelitian ini, menggunakan metode kuesioner dan wawancara. Kuesioner merupakan suatu alat untuk memperoleh data yang berisi pertanyaan maupun pernyataan secara tertulis dan dijawab secara tertulis oleh responden tentang variabel yang diteliti. Sedangkan skala pengukuran data yang digunakan adalah skala Likert.

Pembobotan atas jawaban kuesioner menggunakan 5 skala ordinal yaitu : Sangat Setuju, Setuju, Kurang Setuju, Tidak Setuju dan Sangat Tidak Setuju untuk setiap jawaban responden pada masingmasing variabel yang diteliti. Dalam kuesioner ini nantinya terdapat rancangan pernyataan yang secara logis berhubungan dengan masalah penelitian dan tiap pernyataan akan dimulai berdasarkan bobot yang sudah ditentukan. Dinana pembobotan tersebut penilaianya adalah sebagai berikut:.

1. Apabila jawaban Sangat Setuju (SS) : bobot nilai 5

2. Apabila jawaban Setuju (S) : bobot nilai 4

3. Apabila jawaban Kurang Setuju (KS) : bobot nilai 3
4. Apabila jawaban Tidak Setuju (TS) : bobot nilai 2

5. Apabila Sangat Tidak Setuju (STS) : bobot nilai 1

Oleh karena skala data dalam penelitian ini pengukurannya masih dalam bentuk data dengan skala Likert, dimana data dianggap masih dalam skala ordinal sehingga masih belum memiliki makna, sementara dalam proses analisis regresi mengharuskan data minimal dalam bentuk skala Interval, sehingga data tersebut terlebih dahulu harus di transformasi menjadi data dengan skala interval. Untuk melakukan transformasi data tersebut, salah satu teknik yang dapat dilakukan adalah dengan menggunakan Method of Successive Interval (MSI). Method of Successive Interval (MSI) adalah metode suksesif interval merupakan proses mengubah data Ordinal menjadi data Interval (Sarwono, 2015:250). Dalam penelitan ini hal tersebut nantinya akan dilakukan dengan bantuan program SPSS Versi 21.

\section{Teknik Analisa Data}

Teknik pengolahan data dilakukan sebagai langkah awal dalam penelitian ini. Pengolahan data dilakukan dengan bantuan program SPSS versi 21 for windows evaluation version untuk mengolah hasil perhitungan data yang diperoleh. Setelah itu data diinterpretasikan secara deskriptif. Namun sebelum data dari hasil kuesioner tersebut diolah terlebih dahulu perlu di uji dengan mengunakan uji.

Agar mendapatkan hasil penelitian yang sesuai dengan tujuan penelitian, maka diperlukan metode 
analisis data yang benar, sebelum melakukan pengolahan data dari hasil kuisioner tersebut, terlebih dahulu data di uji dengan mengunakan uji kualitas data. Uji kualitas data dimaksudkan untuk mengetahui seberapa besar tingkat keakuratan dan konsistensi data yang dikumpulkan dari instrumen (daftar pertanyaan) yang digunakan.

Dalam penelitian ini, uji kualitas data dilakukan terhadap instrumen kuesioner penelitian dengan uji validitas dan uji reliabilitas, hal ini dilakukan untuk menguji kuesioner sebagai data primer. Uji kuesioner dilakukan pada 70 responden. Uji kuesioner tersebut dilakukan dengan uji validitas dan uji reliabilitas.

IV.HASIL PENELITIAN \& PEMBAHASAN

\section{Hasil Penelitian}

Pengujian Asumsi Data

Uji Validitas dan Reliabilitas

Uji Validitas (Validity) Kuesioner

Uji validitas akan menguji masing-masing instrumen variabel yang digunakan dalam penelitian ini, dimana keseluruhan instrumen variabel penelitian memuat 46 item pernyataan yang harus dijawab oleh responden. Untuk menentukan valid tidaknya suatu item pertanyaan atau instrumen dilakukan dengan membandingkan harga korelasi antar skor butir dengan skor total yang sudah dikorelasi atau dengan harga rtabel. Jadi hasil dari korelasi tersebut akan dibandingkan dengan rtabel pada tingkat signifikasi 0,05 : apabila nilai Corrected Item-Total Correlation /Pearson Correlation atau rhitung $>$ dari rtabel (nilai $\mathrm{r}$ pada kolom ke $n$ dimana $n=77$ sehinga nilai $\mathrm{r}=0,2213$ ), maka instrumen tersebut adalah valid dan sebaliknya jika rhitung negatif dan rhitung < dari rtabel maka instrumen tersebut tidak valid (Ghozali, 2009).

Diketahui bahwa dari hasil uji validitas menunjukan bahwa keseluruhan nilai pernyataan item variabel penelitian mengasilkan nilai Pearson Correlation atau rhitung-nya diatas nilai rtabel atau rhitung > rtabel. Hal ini menunjukkan bahwa seluruh item variabel dalam penelitian ini berada diatas nilai rhitung yang sebesar 0,2213 sehingga dapat disimpulkan bahwa seluruh item pernyataan dari variabel penelitian ini adalah memenuhi syarat uji validitas, dengan demikian seluruh data tersebut dapat digunakan untuk dianalisa lebih lanjut.

\section{Uji Reliabilitas (reliability)}

\begin{tabular}{lrr}
\multicolumn{2}{c}{ Pengujian } & reliabilitas \\
bertujuan & untuk & memenuhi \\
konsistensi & hasil & pengukuran
\end{tabular} variabel. Pengukuran yang reliabel akan menunjukan instrumen yang sudah dipercaya sehingga dapat menghasilkan data yang dipercaya pula. Pengujian reliabilitas dilakukan dengan cronbach alpha yaitu untuk menguji kelayakan terhadap konsistensi seluruh skala yang digunakan. Suatu instrumen dikatakan reliabel dan dapat digunakan dalam penelitian apabila memiliki croncbach alpha lebih besar atau sama dengan $\geq 0,6$ (Ghozali, 2009).

Berdasarkan hasil uji reliabilitas pada Tabel 4.10 dapat diketahui bahwa koefisien cronbach's alpha instrumen (item pernyataan) penelitian terhadap 
variabel Strategi Bauran Pemasaran $=(\mathrm{X})$, Kinerja Pemasaran $=(\mathrm{Y})$, dan Orientasi Kewirausahaan $=(\mathrm{Z})$ kelompok UPPKS tersebut menunjukan masing-masing koefisien variabel memiliki nilai cronbach's alpha $>0,6$ sehingga dapat disimpulkan bahwa seluruh variabel dalam penelitian ini adalah realibel, yang artinya semua data dapat digunakan untuk di analisa lebih lanjut.

\section{Uji Normalitas Data}

Uji normalitas bertujuan untuk menguji apakah dalam sebuah model regresi, variabel dependent (eksogen), variabel moderating (endogen moderating), variabel independent (endogen) ataupun ketiganya mempunyai distribusi normal atau tidak. Model regresi yang baik adalah distribusi data normal atau mendekati normal (Ghozali, 2009). Uji normalitas yang digunakan dalam penelitian ini adalah menggunakan uji Uji K-S atau Model One Sample Kolmogorov-Smirnov Test. Uji normalitas dengan menggunakan Model One Sample KolmogorovSmirnov Test menurut Ghozali (2009), pedoman pengambilan keputusannya yaitu jika:

1. Nilai signifikan atau probabilitas $<0,05$; berarti distribusi data tidak normal.

2. Nilai signifikan atau probabilitas $>0,05$; berarti distribusi data normal.

Hasil uji normalitas hubungan secara langsung antara variabel independen terhadap variabel dependen dapat diketahui dari Tabel 4.11 berikut:

Tabel 4.11 Uji Normalitas Statistik

\section{Kolomograv-Smirnov Jalur 1}

One-Sample Kolmogorov-Smirnov Test

\begin{tabular}{|ll|r|}
\hline & & \multicolumn{1}{|c|}{ Unstandardized } \\
& Residual \\
\hline $\mathrm{N}$ & & 77 \\
Normal Parameters & Mean & $0 \mathrm{E}-7$ \\
& Std. Deviation & .50447614 \\
& Absolute & .121 \\
Most Extreme Differences & Positive & .121 \\
& Negative & -.107 \\
Kolmogorov-Smirnov Z & & 1.010 \\
Asymp. Sig. (2-tailed) & & .260 \\
\hline
\end{tabular}

a. Test distribution is Normal.

b. Calculated from data.

Sumber: Data Olahan SPSS, Lampiran 4 : Uji K-S Model 1

Data yang terdistribusi normal atau probabilitas diatas 0,05. Dari ditunjukkan jika nilai signifikansi Tabel 4.11, dapat dilihat bahwa hasil 
pengujian normalitas terhadap 77 sampel data penelitian pada jalur 1, menunjukkan bahwa nilai Asymp. Sig. (2-tailed) sebesar 0.260, hal ini berarti seluruh variabel yang terdiri dari : Strategi Bauran Pemasaran = $(\mathrm{X})$, Orientasi Kewirausahaan $=(\mathrm{Z})$, dan Kinerja Pemasaran $=(\mathrm{Y})$ kelompok UPPKS mempunyai nilai signifikansi sebesar 0,260 dimana nilai tersebut > 0,05 ; dengan demikian seluruh data variabel pada panelitian ini dapat dikatakan terdistribusi secara normal, maka model regresi yang digunakan dalam penelitian ini antara pengaruh variabel independen terhadap variabel dependen dapat disimpulkan memenuhi asumsi normalitas, sehingga data dapat dipergunakan untuk di analisa lebih lanjut.

Kemudian untuk hasil uji normalitas secara tidak langsung antara variabel independen terhadap variabel dependen dengan adanya pengaruh variabel moderasi dengan uji K-S dapat diketahui dari Tabel 4.12 berikut:

Tabel 4.12 Uji Normalitas Statistik Kolomograv-Smirnov Jalur 2

One-Sample Kolmogorov-Smirnov Test

\begin{tabular}{|ll|r|}
\hline & & \multicolumn{1}{|c|}{$\begin{array}{c}\text { Unstandardized } \\
\text { Residual }\end{array}$} \\
\hline $\mathrm{N}$ & Mean & 77 \\
Normal Parameters & aE- & $0 \mathrm{E}$ \\
& Std. Deviation & .41146479 \\
& Absolute & .082 \\
Most Extreme Differences & Positive & .068 \\
& Negative & -.082 \\
Kolmogorov-Smirnov Z & & .682 \\
Asymp. Sig. (2-tailed) & & .740 \\
\hline
\end{tabular}

a. Test distribution is Normal.

b. Calculated from data.

Sumber: Data Olahan SPSS, Lampiran 4 : Uji K-S Normalitas Model 2 dengan demikian seluruh data

Dari Tabel 4.12, dapat dilihat bahwa hasil pengujian normalitas terhadap 77 sampel data penelitian pada jalur 2, menunjukkan bahwa nilai Asymp. Sig. (2-tailed) sebesar 0.740 , hal ini berarti seluruh variabel yang terdiri dari : Strategi Bauran Pemasaran $=(\mathrm{X}), \quad$ Orientasi Kewirausahaan $=(\mathrm{Z})$, dan Kinerja Pemasaran $=(\mathrm{Y})$ kelompok UPPKS mempunyai nilai signifikansi sebesar 0,740 dimana nilai tersebut $>0,05$; variabel pada panelitian ini terdistribusi secara normal, maka model regresi yang digunakan dalam penelitian ini antara pengaruh variabel independen terhadap variabel dependen dengan adanya pengaruh variabel moderasi dapat disimpulkan memenuhi asumsi normalitas, sehingga data dapat

dipergunakan untuk di analisa lebih lanjut. 


\section{Hasil Uji Multikolinearitas}

Multikolinearitas

menunjukkan bahwa antara variabel independen mempunyai hubungan langsung (korelasi) yang sangat kuat (Ghozali, 2009). Menurut Ghozali (2009), multikolinearitas terjadi jika:

1. Nilai Variance Inflation Factor (VIF) lebih < dari 10 atau nilai Tolerance lebih > 0,1 maka variabel tersebut memiliki pengaruh multikolonearitas.
2. Dan sebaliknya jika nilai Variance Inflation Factor (VIF) dibawah 10 dan mempunyai nilai Tolerance mendekati angka 1, maka dianggap bebas dari pengaruh multikolonearitas.

Nilai Tolerance dan Variance Inflation Factor (VIF) hubungan secara langsung antara variabel independen terhadap variabel dependen dapat diketahui dari Tabel 4.13 sebagai berikut:

Tabel 4.13 Hasil Pengujian Multikolonearitas Jalur 1

\begin{tabular}{|ll|c|c|}
\hline \multirow{2}{*}{\multicolumn{2}{|c|}{ Model }} & \multicolumn{2}{c|}{ Collinearity Statistics } \\
\cline { 3 - 4 } & & Tolerance & VIF \\
\hline $1 \quad$ (Constant) & 0.595 & 1.680 \\
& Bauran Pemasaran & 0.595 & 1.673 \\
\hline
\end{tabular}

Sumber : Data Olahan SPSS, Lampiran 4.

Berdasarkan Tabel 4.13, diatas dapat diketahui bahwa nilai VIF variabel Bauran Pemasaran sebesar 1,680 dan Orientasi Kewirausahaan sebesar 1,673. Berdasarkan hasil perhitungan tersebut dapat dilihat bahwa nilai VIF ke dua variabel bebas tersebut lebih kecil dari 10 dan nilai tolerance-nya mendekati 1 , sehingga dapat disimpulkan bahwa tidak terjadi multikolinearitas atau gejala korelasi antar variabel tersebut.
Sedangkan Nilai Tolerance dan Variance Inflation Factor (VIF) hubungan secara tidak langsung antara variabel independen terhadap variabel dependen dengan adanya pengaruh variabel moderasi dapat diketahui dari Tabel 4.14 berikut:

Dari hasil perhitungan nilai tolerance pada hasil analisis data, diperoleh nilai VIF < 10), dengan nilai tolerance $>0.10$, sehingga dapat disimpulkan bahwa model regresi tersebut bebas dari multikolinieritas.

Tabel 4.14 Hasil Pengujian Multikolonearitas Jalur 2

\begin{tabular}{|ll|c|c|}
\hline \multirow{2}{*}{ Model } & \multicolumn{2}{|c|}{ Collinearity Statistics } \\
\cline { 2 - 3 } & Tolerance & VIF \\
\hline $1 \quad \begin{array}{l}\text { (Constant) } \\
\text { Bauran Pemasaran }\end{array}$ & 0.555 & 1.645 \\
\hline
\end{tabular}

Sumber : Data Olahan SPSS, Lampiran 4. 
Berdasarkan Tabel 4.14

diatas dapat diketahui bahwa nilai VIF variabel Bauran Pemasaran sebesar 1,645. Berdasarkan hasil perhitungan tersebut dapat dilihat bahwa nilai VIF variabel bebas lebih kecil dari 10 dan nilai tolerance mendekati 1, sehingga dapat disimpulkan bahwa tidak terjadi multikolinearitas atau gejala korelasi.

\section{Hasil Uji Autokolerasi}

Untuk mendeteksi autokorelasi atau hubungan yang terjadi diantara anggota-anggota dari serangkaian pengamatan yang tersusun dalam rangkaian waktu maupun tersusun dalam rangkaian ruang yang disebut data cross sectional dalam penelitian ini digunakan uji Durbin Watson (DW) dengan melihat DW test. Menurut Algifari (2010), untuk mengetahui terjadinya autokorelasi digunakan uji Durbin Watson (DW).

Hasil uji autokorelasi berdasarkan pengolahan data yang dilakukan dengan bantuan program SPSS Versi 21 untuk hubungan secara langsung antara variabel independen terhadap variabel dependen dapat ditunjukan seperti pada Tabel 4.16 berikut:

\section{Tabel 4.16 Hasil Pengujian Autokorelasi Jalur 1}

\begin{tabular}{|l|r|r|r|r|r|}
\hline Model & R & R Square & $\begin{array}{c}\text { Adjusted R } \\
\text { Square }\end{array}$ & $\begin{array}{c}\text { Std. Error of } \\
\text { the Estimate }\end{array}$ & $\begin{array}{c}\text { Durbin- } \\
\text { Watson }\end{array}$ \\
\hline 1 & $.779^{\text {a }}$ & .607 & .595 & .41756 & 1.914 \\
\hline
\end{tabular}

a. Predictors: (Constant), Bauran Pemasaran, Orientasi Kewirausahaan

b. Dependent Variable: Kinerja Pemasaran Sumber : Data Olahan SPSS, Lampiran 4.

Dari perhitungan SPSS for windows versi 21, dalam Tabel 4.17 tersebut, terlihat hasil nilai Durbin Watson (DW) sebesar 1,914 dimana nilai DW tersebut terletak diantara 1,55 sampai dengan 2,46 dengan kesimpulan tidak ada autokorelasi antar masing-masing variabel bebas, sehingga model regresi yang terbentuk dari nilai variabel terikat hanya dijelaskan oleh variabel bebas saja.

Sedangkan hasil uji autokorelasi untuk hubungan secara tidak langsung antara variabel independen terhadap variabel dependen dengan adanya pengaruh variabel moderasi dapat ditunjukan seperti pada Tabel 4.17 berikut: 
PENGARUH STRATEGI BAURAN PEMASARAN TERHADAP KINERJA PEMASARAN DENGAN ORIENTASI KEWIRAUSAHAAN SEBAGAI VARIABEL PEMODERASI PADA UPPKS (USAHA PENINGKATAN PENDAPATAN KELUARGA SEJAHTERA) DI KOTA PEKANBARU PEKANBARU

Tabel 4.17 Hasil Pengujian Autokorelasi Jalur 2

Model Summary ${ }^{b}$

\begin{tabular}{|l|r|r|r|r|r|}
\hline Model & \multicolumn{1}{|c|}{$\mathrm{R}$} & R Square & $\begin{array}{l}\text { Adjusted } \\
\text { R Square }\end{array}$ & $\begin{array}{l}\text { Std. Error of } \\
\text { the Estimate }\end{array}$ & $\begin{array}{c}\text { Durbin- } \\
\text { Watson }\end{array}$ \\
\hline 1 & $.636^{\mathrm{a}}$ & .405 & .396 & .50817 & 1.813 \\
\hline
\end{tabular}

a. Predictors: (Constant), Bauran Pemasaran

b. Dependent Variable: Orientasi Kewirausahaan

Sumber : Data Olahan SPSS, Lampiran 4.

Dari perhitungan SPSS for

windows versi 21, dalam Tabel 4.17 tersebut, terlihat hasil nilai Durbin Watson (DW) sebesar 1,814 dimana nilai DW tersebut terletak diantara 1,55 sampai dengan 2,46 dengan kesimpulan tidak ada autokorelasi antar masing-masing variabel bebas, sehingga model regresi yang terbentuk dari nilai variabel terikat hanya dijelaskan oleh variabel bebas saja.

\section{Hasil Uji Heteroskedastisitas}

Model regresi yang baik adalah model yang tidak terjadi heteroskedastisitas. Untuk mengetahui ada tidaknya heteroskedastisitas antar variabel independen dapat dilihat dari grafik Scatterplot yakni untuk menggambarkan antara nilai prediksi variabel terikat dengan residualnya. Heteroskedastisitas dalam penelitian ini bisa dilihat dengan melihat grafik scatterplot antara nilai prediksi variabel dependen dengan residualnya. Dasar pengambilan keputusan melalui grafik scatterplot adalah sebagai berikut:

1. Jika ada pola tertentu yaitu membentuk pola yang teratur, maka terjadi heterokedasitisitas.

2. Jika tidak ada pola yang jelas yaitu titik-titik membentuk pola yang tidak teratur dan menyebar disumbu Y, maka tidak terjadi heterokedasitisitas.

Adapun grafik hasil pengujian heterokesdastisitas dengan bantuan program SPSS Versi 21 untuk hubungan secara langsung antara variabel independen terhadap variabel dependen dapat dilihat seperti pada Gambar 4.11 sebagai berikut:

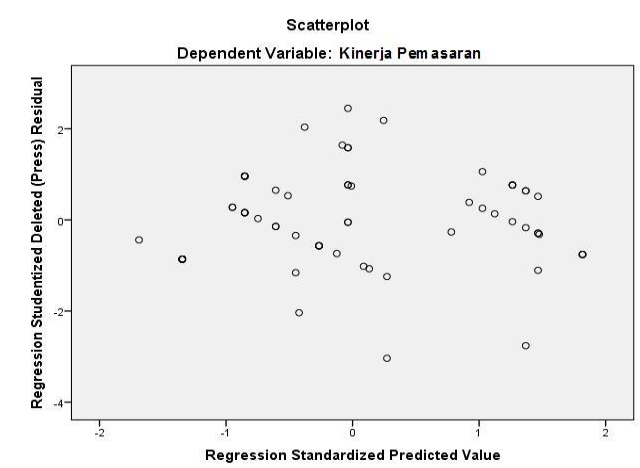

$\begin{array}{ll}\text { Sumber : } & \begin{array}{l}\text { Data Olahan SPSS, } \\ \text { Lampiran } 4 .\end{array}\end{array}$

Dari Gambar 4.11, tersebut dapat dilihat bahwa data terpencar disekitar angka nol pada sumbu Y dan tidak membentuk suatu pola atau trend garis tertentu. Oleh karena itu dapat disimpulkan bahwa tidak terjadi heterokedastisitas pada model analisis penelitian jalur 1 , hal ini artinya tidak terjadi ketidaksamaan varian dari satu variabel bebas kevariabel bebas lain. 


\section{Sedangkan \\ pengujian}

heterokesdastisitas untuk hubungan secara tidak langsung antara variabel independen terhadap variabel dependen dengan adanya pengaruh variabel moderasi dapat dilihat seperti pada Gambar 4.12 berikut:

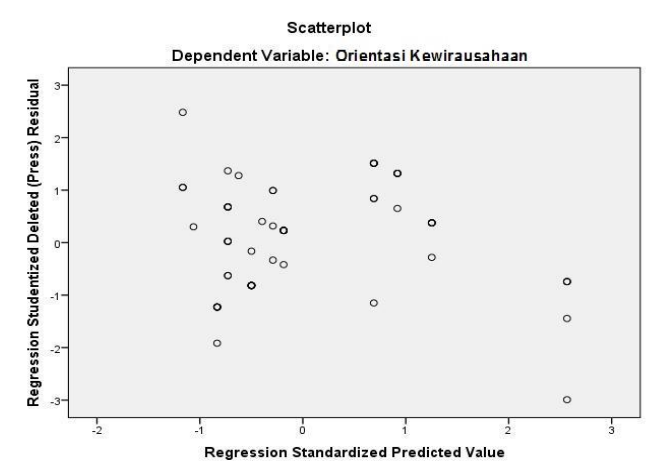

Sumber : Data Olahan SPSS, Lampiran 4

Dari Gambar 4.12, tersebut dapat dilihat bahwa data terpencar disekitar angka nol pada sumbu Y dan tidak membentuk suatu pola atau trend garis tertentu. Oleh karena itu dapat disimpulkan bahwa tidak terjadi heterokedastisitas pada model analisis penelitian jalur 2, hal ini artinya tidak terjadi ketidaksamaan varian dari satu variabel bebas kevariabel bebas lain.

\section{Analisis Jalur (Path Analysis)}

Tahapan pengujian analisis jalur dimaksudkan untuk menguji besarnya kontribusi langsung dan tidak langsung dari variabel Bauran Pemasaran $=(\mathrm{X})$ terhadap Kinerja Pemasaran $=(\mathrm{Y})$, yang dimoderasi oleh variabel Orientasi Kewirausahaan $=(\mathrm{Z})$.

\section{Pengaruh Strategi Bauran Pemasaran terhadap Kinerja Pemasaran}

Hasil penelitian menunjukkan bahwa secara langsung Bauran Pemasaran memiliki pengaruh yang signifikan terhadap Kinerja Pemasaran. Hal ini berarti Bauran Pemasaran dapat mempengaruhi Kinerja Pemasaran, setiap ada upaya perbaikan terhadap Strategi Bauran Pemasaran maka akan dapat berpengaruh positif terhadap meningkatnya Kinerja Pemasaran Kelompok UPPKS. Semakin baik pola penerapan Bauran Pemasaran yang dilakukan oleh Kelompok UPPKS dalam memasarkan produkproduk yang dihasilkan maka hal tersebut dapat meningkatkan Kinerja Pemasaran.

Kurang baiknya Strategi
Bauran Pemasaran kelompok
UPPKS tersebut memberikan
gambaran bahwa salah satu
kelemahan yang dihadapi kelompok
UPPKS adalah dalam hal pemasaran
sehingga perlu adanya strategi baik
dari kelompok UPPKS sendiri dalam
upanya untuk meningkatkan
penjualan serta perlunya pembinaan
terkait dengan Strategi Buran
Pemasaran dimana dari 4 P dalam
Strategi Buran Pemasaran terlihat
betul bahwa Promosi yang dilakukan
oleh kelompok UPPKS sangat
kurang dan masih terbatas pada
adanya pameran saja. Kelemahan ini
harus menjadi perhatian melalui
lembaga tidak hanya dari BKKBN
Kota Pekanbaru saja tetapi perlu juga
melibatka lembaga atau dinas terkait
dalam hal ini adalah Kementerian
Koperasi dan Usaha Kecil dan
Menengah melalui dinas Koperasi
dan UMKM bidang UMKM Industri
kelemahan yang dihadapi kelompok UPPKS adalah dalam hal pemasaran sehingga perlu adanya strategi baik dari kelompok UPPKS sendiri dalam upanya untuk meningkatkan penjualan serta perlunya pembinaan terkait dengan Strategi Buran Pemasaran dimana dari $4 \mathrm{P}$ dalam Strategi Buran Pemasaran terlihat betul bahwa Promosi yang dilakukan oleh kelompok UPPKS sangat kurang dan masih terbatas pada adanya pameran saja. Kelemahan ini harus menjadi perhatian melalui lembaga tidak hanya dari BKKBN Kota Pekanbaru saja tetapi perlu juga melibatka lembaga atau dinas terkait dalam hal ini adalah Kementerian Koperasi dan Usaha Kecil dan dan UMKM bidang UMKM Industri 
Kreatif juga harus harus lebih sering memberikan pelatihan dan bimbingan kepada para pelaku usaha yang tergabung dalam kelompok UPPKS agar mereka dapat menciptakan inovasi dalam memasarkan produk yang dihasilkan terutama menggunakan Strategi Bauran Pemasaran dengan memanfaatkan media sosial karena lebih mudah dan berdampak luas dimasyarakat.

\section{Pengaruh \\ Orientasi \\ Kewirausahaan terhadap Kinerja Pemasaran}

Hasil penelitian menunjukkan bahwa secara langsung Orientasi Kewirausahaan memiliki pengaruh yang signifikan terhadap Kinerja Pemasaran. Hal ini berarti Orientasi Kewirausahaan dapat mempengaruhi Kinerja Pemasaran, setiap adanya upaya yang baik dalam meningkatkan Orientasi Kewirausahaan para pengelola ataupun para pelaku usaha yang tegabung dalam Kelompok UPPKS maka akan dapat berpengaruh positif terhadap meningkatnya Kinerja Pemasaran Kelompok UPPKS. Semakin baik jiwa keorientasian kewirausahaan yang dimiliki oleh pengelola ataupun para pelaku susaha yang tergabung dalam Kelompok UPPKS maka hal tersebut dapat meningkatkan Kinerja Pemasaran.

Kurang baiknya Orientasi Kewirausahaan kelompok UPPKS tersebut memberikan gambaran bahwa dalam berusaha para pengelola kelompok UPPKS memang masih belum memiliki Orientasi Kewirausahaan yang semestinya diperlukan sebagai seorang wirausaha, sehigga masih perlu banyak bimbingan dan arahan dari lembaga terkait terutama dari BKKBN Kota Pekanbaru sebagai pembina serta perlu juga melibatkan dinas terkait dalam hal ini Kementerian Koperasi dan Usaha Kecil dan Menengah melalui dinas Koperasi dan UMKM bidang UMKM Industri Kreatif juga harus harus lebih sering memberikan pelatihan dan bimbingan kepada para pelaku usaha yang tergabung dalam kelompok UPPKS agar mereka memiliki jiwa sebagai seorang wirausaha demi kesejahteraan kelompok UPPKS-nya.

\section{Pengaruh Moderasi Orientasi Kewirausahaan pada Strategi Bauran Pemasaran terhadap Kinerja Pemasaran}

Hasil penelitian menunjukkan bahwa secara tidak langsung Strategi Bauran Pemasaran jika dimoderasi oleh Orientasi Kewirausahaan memiliki pengaruh yang signifikan terhadap Kinerja Pemasaran yang dibuktikan dari nilai thitung > ttabel dengan derajat signifikansi Sig. pvalue $<0,05$. Kemudian jika melihat bahwa besaran dari pengaruh langsung Bauran Pemasaran terhadap Kinerja Pemasaran sebelum dan sesudah adanya variabel moderating yakni Orientasi Kewirausahaan menunjukkan hasil yang berbeda, dimana pengaruh langsung sebelum adanya variabel moderating adalah sebesar 0,328 dan sesudah adanya variabel moderating sebesar 0,636. Artinya pengaruh Bauran Pemasaran sesudah adanya variabel moderating (Orientasi Kewirausahaan) lebih besar daripada sebelum adanya variabel moderating (Orientasi 
Kewirausahaan) terhadap Kinerja Pemasaran yakni 0,328 sebelum dan 0,636 sesudah. Dengan demikian dapat disimpulkan bahwa variabel moderating

(Orientasi

Kewirausahaan) merupakan variabel yang sangat dibutuhkan karena dapat meningkatkan pengaruh Bauran Pemasaran terhadap Kinerja Pemasaran.

Pada intinya semua pelaku usaha yang berada di lingkungan persaingan bisnis mempunyai keinginan untuk lebih unggul dibandingkan dengan pelaku usaha lainya. Strategi pemasaran merupakan alat fundamental yang direncanakan untuk mencapai tujuan perusahaan dengan mengembangkan keunggulan bersaing yang berkesinambungan melalui pasar yang dimasuki dan program pemasaran yang digunakan untuk melayani pasar sasaran tersebut (Tjiptono, 2014:371). Adanya persaingan yang terjadi dalam setiap usaha pada masa lalu sehingga strategi pemasaran perlu disesuaikan. Strategi pemasaran menjadi kunci kesuksesan perusahaan dalam era globalisasi, sementara orientasi kewirausahaan dipandang sebagai sebuah seni dalam melihat tantangan dan peluang yang sedang dihadapi.

Orientasi kewirausahaan adalah kecenderungan organisasi untuk menerima proses, praktek dan pengambilan keputusan entrepreneurial yang ditandai dengan preferensi terhadap innovativeness, risk taking (keberanian mengambil risiko) dan proactiveness (Matsuno, Mentzer, dan Ozsomer, 2012). Orientasi kewirausahaan berkaitan dengan jiwa atau karakteristik personal dari pemilik perusahaan dan mewarnai perusahaan tersebut.

Kedua hal ini yaitu strategi pemasaran dan orientasi kewirausahaan tampaknya sudah menjadi satu kesatuan yang tidak terpisahkan. Ketiganya dipandang sebagai faktor yang mempengaruhi upaya perusahaan untuk meningkatkan kinerja pemasarannya. Hasil penelitian Karinda, Lisbeth dan Mananeke (2018), menunjukkan bahwa strategi pemasaran memiliki pengaruh positif terhadap kinerja pemasaran. Kemudian terkait dengan orientasi kewirausahaan hasil penelitian Yusri dan Djasuro (2017), menunjukkan bahwa orientasi kewirausahaan adalah kunci untuk meningkatkan kinerja pemasaran. Perusahaan yang pimpinannya berorientasi wirausaha memiliki visi yang jelas dan berani untuk menghadapi resiko sehingga mampu menciptakan kinerja yang lebih baik. Sehingga dalam hal ini para pelaku usaha yang tergabung dalam kelompok UPPKS harus mampu dan semaksimal mungkin melakukan uapaya untuk selalu mencipkatan peluang-peluang terhadap terciptanya penjualan dan harus lebih banyak belajar tidak hanya dari para pembimbingnya tetapi juga dari para pelaku usaha yang berhasil bagai mana cara mereka dalam memasarkan produk dan bagaimana jiwa mereka dalam orientasi kewirausahaan sehingga diharapkan mereka dapat mengembangakan usahannya.

\section{SIMPULAN DAN SARAN Simpulan}

1. Bauran Pemasaran memiliki pengaruh yang signifikan 
terhadap Kinerja Pemasaran. Semakin baik pola penerapan Strategi Bauran Pemasaran yang dilakukan oleh para pelaku usaha yang tergabung dalam kelompok UPPKS, maka akan semakin dapat meningkatkan Kinerja Pemasaran.

2. Orientasi Kewirausahaan memiliki pengaruh yang signifikan terhadap Kinerja Pemasaran. Semakin baik jiwa keorientasian kewirausahaan yang dimiliki oleh pengelola ataupun para pelaku usaha yang tergabung dalam Kelompok UPPKS maka hal tersebut dapat meningkatkan Kinerja Pemasaran.

3. Strategi Bauran Pemasaran jika dimoderasi oleh Orientasi Kewirausahaan memiliki pengaruh yang signifikan terhadap Kinerja Pemasaran. Pengaruh Bauran Pemasaran sesudah adanya variabel moderating (Orientasi Kewirausahaan) lebih besar daripada sebelum adanya variabel moderating (Orientasi Kewirausahaan) terhadap Kinerja Pemasaran. Orientasi Kewirausahaan merupakan variabel yang sangat dibutuhkan karena dapat meningkatkan pengaruh Bauran Pemasaran terhadap Kinerja Pemasaran.

\section{Saran}

Berdasarkan kesimpulan di atas, maka dapat diberikan beberapa saran sebagai berikut:

1. Guna meningkatkan Kinerja Pemasaran kelompok UPPKS hal yang perlu ditingkatkan adalah: Perlunya bantuan pihak ketiga dalam hal ini lembaga terkait baik dari dari BKKBN mupun Dinas Koperasi dan UKM bidang UMKM Industri Kreatif agar lebih sering memberikan pelatihan dan bimbingan sehingga mereka dapat menciptakan inovasi dalam pengembangan pasar terutama untuk mempromosikan dan mengiklankan produk yang dihasilkan melalui media sosial yang terpadu sehingga lebih mudah diakses, murah dan berdampak luas dimasyarakat.

2. Dari segi Bauran Pemasaran hal yang perlu ditingkatkan adalah sesama anggota kelompuk harus saling terbuka dan saling berkerja sama serta informasi tentang produk sebaiknya tidak hanya dilakukan dengan mengikuti pameran-pameran dan dari mulut kemulut saja tetpi harus dapat diintergrasikan dalam suatu bentuk bauran pemasaran yang lebih dapat menjangkau luas. Perlu adanya strategi baik dari kelompok UPPKS sendiri dalam upanya untuk meningkatkan penjualan serta perlunya pembinaan terkait dengan Strategi Buran 
Pemasaran dimana dari $4 \mathrm{P}$ dalam Strategi Buran Pemasaran.

3. Dari segi Orientasi kewirausahaan hal yang perlu ditingkatkan adalah: Perlunya meningkatkan kemampuan dan pengetahuan para pelaku terutama para pengelola kelompok UPPKS masih perlu banyak bimbingan dan arahan dari lembaga terkait terutama dari BKKBN Kota Pekanbaru sebagai pembina serta perlu juga melibatkan dinas terkait dalam hal ini Kementerian Koperasi dan Usaha Kecil dan Menengah melalui dinas Koperasi dan UMKM bidang UMKM Industri Kreatif juga harus harus lebih sering memberikan pelatihan dan bimbingan kepada para pelaku usaha yang tergabung dalam kelompok UPPKS agar mereka memiliki jiwa sebagai seorang wirausaha demi kesejahteraan kelompok UPPKS-nya.

\section{DAFTAR PUSTAKA}

Algifari. 2010. Metode Riset Bisnis. CV. Andi Offset.Yogyakaarta.

Angelita dan Silvya. 2018. Pengaruh Inovasi Produk, Tempat Dan Promosi Terhadap Kinerja Pemasaran Motor Suzuki (Pada PT. Sinar Galesong Mandiri Cab. Malalayang). Jurnal EMBA. Vol.6 No. 4: 3348-3357. Universitas Sam Ratulangi Manado.
Buchari, Alma. 2014. Manajemen Pemasaran dan Pemasaran Jasa. Penerbit Alfabeta. Bandung.

Fatma, Ida. 2014. Efektivitas Program Usaha Peningkatan Pendapan Keluarga Sejahtera (UPPKS) Kecamatan Jetis, Kabupaten Bantul, Propinsi Daerah Istimewa Yogyakarta. Tesis. UMY. Yogyakarta.

Ferdinand, Augusty. 2014. Metode Penelitian Manajemen. BP Universitas Diponegoro. Semarang.

Fiandri. 2016. Marketing MIX Analysis On The Performance Of Marketing On Micro, Small, and Medium Enterprises (MSME) Fashion Sector In Depok West Java. SEMNAS FEKON.

Ghozali, Imam, 2009. Aplikasi Analisis Multivariat dengan Program IBM SPSS 21. Edisi 5. Penerbit Universitas Diponegoro. Semarang.

Hendri. 2016. Analisis Komparatif Pengaruh Lingkungan Makro Dan Mikro Dalam Perumusan Strategi Pemasaran Industri Mikro Kecil (IMK) Dan Dampaknya Terhadap Kinerja Pemasaran (Survei Pada Kelompok IMK Produk Makanan dan IMK Produk Non Makanan Di Kabupaten Cianjur Tahun 2014). Tesis (Tidak Dipulbikasikan). 
Inpres Nomor 3 Tahun 1996 tentang

Pembangunan Keluarga

Sejahtera Dalam Rangka

Peningkatan Penanggulan

Kemiskinan.

Karinda, Lisbeth dan Mananeke. 2019. Meningkatkan Kinerja Pemasaran UMKM Kota Semarang Melalui Strategi Penetrasi Pasar. Jurnal EMBA. Vol.6 No. 3. Hal. 1568 - 1577. Universitas Sam Ratulangi Manado.

Kotler, P dan Keller L. 2014. Manajemen Pemasaran. Jilid 2. Edisi ke - 15 Alih Bahasa Bob Sabran. MM. Erlangga. Jakarta.

Matsuno, K., J. T. Mentzer, and A. Ozsomer. 2012. The Effect Entrepreneurial Proclivity and Market Orientation on Business Performance. Journal of Marketing. 66 (3): 18-33. 